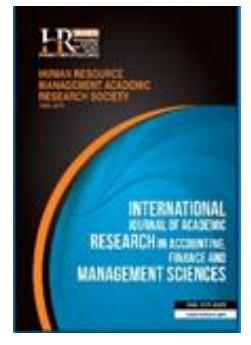

International Journal of Academic Research in Accounting, Finance and Management Sciences

Vol. 9, No.1, January 2019, pp. 21-29

E-ISSN: 2225-8329, P-ISSN: 2308-0337

(c) 2018 HRMARS

www.hrmars.com

To cite this article: Chukwu, G. J., Ugo, C. C., Osisioma B. C. (2019). Market Valuation of Human Capital in Nigerian Banks, International Journal of Academic Research in Accounting, Finance and Management Sciences 9 (1): 21-29.

\title{
Market Valuation of Human Capital in Nigerian Banks
}

\section{Gospel J. Chukwu' ${ }^{1}$, Chibuike Camillus Ugo ${ }^{2}$, Benjamin C. Osisioma ${ }^{3}$}

${ }^{1}$ Ken Saro-Wiwa Polytechnic, Bori, Rivers State, Nigeria, ${ }^{1}$ Email: gospeljchukwu@gmail.com (Corresponding author)

${ }^{2}$ Ignatius Ajuru University of Education, Rumuolumeni, Port Harcourt, Nigeria

${ }^{3}$ Nnamdi Azikiwe University, Awka, Nigeria

\begin{abstract}
This paper examines the effect of human capital on the market value of banks in Nigeria, using data on three proxies of human capital related to remuneration and staff strength. Relevant financial statement data (for the period 2010 to 2014) were extracted from the annual reports and accounts of fourteen banks listed on the Nigerian Stock Exchange. Results of regression of stock price on the human capital indicators show that only one variable - the proportion of highly paid employees - had a significant effect on the market value of firms. The findings suggest that investors' confidence increases with the strength of valuable stock of human capital in the payroll of banks. Banks that are unable to retain a high proportion of highly paid employees in their staff structure may consider merging with other banks to sustain investors' confidence. The study also has implications for the remuneration committees of banks as the proportion of highly paid employees at the firm level affects the confidence of equity investors.

Key words Human capital, number of highly paid employees, overall staff strength, proportion of highly paid employees, value relevance

Received: 08 Mar 2019 (C) The Authors 2019

Revised: 20 Mar 2019 Published by Human Resource Management Academic Research Society (www.hrmars.com)

Accepted: 30 Mar 2019 This article is published under the Creative Commons Attribution (CC BY 4.0) license. Anyone may Published Online: $25 \mathrm{Apr} 2019$ reproduce, distribute, translate and create derivative works of this article (for both commercial and non-commercial purposes), subject to full attribution to the original publication and authors. The full terms of this license may be seen at: http://creativecommons.org/licences/by/4.0/legalcode
\end{abstract}

\section{Introduction}

The twenty-first century has witnessed accelerated economic growth, globalization, deregulation, fast-changing business environment and strong technological developments. These have resulted in a fundamental shift in the global system from a mass production-based economy to a knowledge-based economy. In this new economy, tangible assets such as property, plant and equipment will continue to be important factors of production; but their relative importance as competitive weapons has decreased and will continually decrease over time. As international competitiveness continue to intensify and information technologies rapidly advance, knowledge will increasingly become the critical factor affecting an organization's ability to remain competitive in the new global market. Accordingly, a business must devise a mechanism for tapping into the collective knowledge and abilities of its employees in order to create and sustain competitive advantage in the current turbulent economic environment (Rastogi, 2000; Seetharaman et al., 2002; Carson et al., 2004; Bilich and Silva, 2006; Bose and Thomas, 2007; Arenas and Lavenders, 2008).

Human capital can deal with business turbulence because of its ability to adapt to changes in the socio-economic environment. It is a major component of an organization's intangible resources; indeed, the "key intangible form of value creation" (Royal and O' Donnell, 2008). It is reasonable, therefore, to expect 
that the market would value the resource from which a business derives its sustainable, competitive advantage (Bryant-Kutcher et al., 2009).

The excess of market value over the book value of firms (sometimes referred to as market value added) and the contribution of intangible values to this gap have been actively debated in the last decade by researchers in intellectual capital measurement. Many of these studies have argued that this excess represents a class of intangible resources known as intellectual capital which are not captured in traditional financial statements (Bilich and Silva, 2006; Seetharaman et al., 2002; Wang, 2008). However, studies carried out by Pricewaterhouse-coopers in about 1000 companies from 47 countries could not establish any link between human capital assets and the bottom line (Gadzar, 2007). Also, Tayles et al. (2002) have argued that equating this difference solely to the value of intangible assets ignores the earnings potential of a firm's tangible assets which could contribute to the market value added.

In the face of these conflicting views, and to enable better allocation of scarce social capital, there is need for more empirical studies to establish the link, if any, between human capital assets and market valuation of firms. This paper examines the relationship between market value and two categories of human capital - generic human capital and industry-specific human capital.

\section{Literature Review}

\subsection{Concept of Human Capital}

The term "human capital" may be traced to T.W. Schultz who viewed human capital as possessing innate or acquired abilities that are valuable for organizational success (Armstrong, 2006). Human capital is generally understood as the sum of knowledge, skills, attitudes, vigor, talent and motivations that enables an employee to contribute to organizational productivity (Zhang and Jin 2006; Dressler, 2008).

Knowledge and skills used in productive activities may be broadly classified into generic and specific. General human capital refers to skills and knowledge that are useful across different firms and industries. This form of human capital is produced and enhanced by formal education and trainings. Specific human capital are skills and knowledge whose productive value is relevant to activities in a limited context such as a firm (firm-specific), industry (industry-specific), or profession (occupation-specific). Firm-specific human capital is produced and enhanced by on-the-job trainings and long years of experience in a firm. Its usefulness in one firm can hardly be transferred to another firm without substantial investments. Industryspecific capital is accumulated by formal education, on-the-job trainings and practical industrial experience. Occupation-specific human capital is derived from formal education in the relevant discipline, professional trainings, and years of professional practice (Laroche et al., 1999; Swart, 2006; Gowan and Lepak, 2007).

Human capital may be differentiated based on several dimensions such as value and uniqueness. A resource is valuable when it contributes to organizational efficiency and effectiveness (Barney, 1991); and unique, when it is specialized, rare, and cannot be readily sourced from the labour market (Lepak and Snell, 2002). Valuable and unique human capital is an important tool in sustaining the strategic, competitive advantage of a firm (Barney, 1991).

The usefulness of human capital transcends organization settings as it is applicable to various socioeconomic contexts. This broad view is supported by the Organization for Economic Co-operation and Development (OECD) in its definition of human capital as "the knowledge, skills, competencies and attributes embodied in individuals that facilitate the creation of personal, social and economic well-being" (OECD, 2001 p. 19). The knowledge and skills embodied in individuals are multi-faceted in nature, contextdependent in its accumulation and un-observable in its dimensions. Accordingly, human capital is a multiplex concept (Barney, 1991; OECD, 2001; Le et al., 2003).

\subsection{Measurement of Human Capital}

It is difficult to measure the knowledge and skills embodied in individuals because human capital is intangible and its development is context-dependent. Accordingly, to estimate the stock of human capital would involve the construction of proxies that are relevant to the context of the study (Le et al., 2003). Human capital measures for country-level studies, for instance, may adopt output-based, income-based and cost-based approaches (Kwon, 2009); while firm-level measures may rely on proxies appropriate to the industry. A plethora of proxies have been developed by several researchers with the consequence that a 
reporting entity can chose any set of indicators that will maximize its objectives (Abeysekera, 2008). Financial measures, for instance, are criticized for failing to capture human behavior, attitudes and transfer of tacit knowledge. Moreover, they may become too complex if they include many variables (Kannan and Albur, 2004). Non-financial measures, on the other hand, are sometimes too qualitative, broad, rigid, static and cumbersome to implement (Bontis et al., 1999; Chong, 2008). Non-financial measures that involve perceptual evidence may attempt to measure human factors (such as attitudes) but may not be generalizable as causal relations may be difficult to establish (Kannan and Albur, 2004).

There are measures of human capital contained in models that deal with financial and non-financial measures of intangible assets. These models include Economic Value Added, Skandia Navigator, Technology Broker and Value Explorer. Economic value added (EVA) was introduced by Stern Stewart organization as a model that will measure managerial performance; especially, the extent to which organizational value has been added (Bontis, et al., 1999). Defined as net operating profit less tax and capital charges, EVA can be converted to a human capital measure by dividing it by the number of full time employees in an organisation. With such conversion, EVA will become human capital value added (HEVA) - a measure of how much economic value added can be attributed to individual employees (Fitz-enz, 2009). Another model which measures intangible assets is the Skandia Navigator. This model was motivated by the excess of market value over book value which suggests that there are other assets contributing to corporate value that are not captured by financial statements of reporting entities. The Skandia Navigator focuses on five dimensions of organizational value drivers described as financial focus, customer focus, process focus, renewal and development focus, and human focus which is measured by factors such as number of employees and number of days spent on job trainings (Edvinsson and Malone, 1997 cited in Sulunjaku, 2014). As can be seen from the description of EVA and Skandia Navigator, these models were not developed solely for the measure human capital; accordingly, they may not be able to measure the different dimensions of human capital.

Despite the deficiencies associated with various measurement approaches, organizations continually use human capital measures to provide information on the quality of their workforce, either as supplementary information to financial statements or as notes to the accounts. Some measures may be derived from personnel and other information disclosed in annual financial statements. Three categories of human capital measures are briefly considered below.

Staff cost. The remuneration system in a knowledge-based industry is an important management system which could serve to motivate the work-force and retain high quality human capital. Employee remuneration is therefore an important human capital measure in knowledge intensive industries. These measures could include overall staff cost, staff cost per employee, remuneration of key personnel, remuneration of top senior executives and share-based payments (Cheng et al., 2006; Fitz-enz, 2009)

Staff Strength. Number of employees is a popular human capital measure disclosed in annual reports and accounts of many organizations. This proxy can take various forms such as overall staff strength, number of key personnel, number of star scientists, and number of managers (Darby et al., 1999; Cheng et al., 2006; Wang, 2006). Many other useful proxies on staff strength can be developed.

As noted earlier, there is a variety of human capital measures; some are constructed by reporting entities, others developed by researchers. The construction and use of different human capital measures places reporting entities in different contexts, and diminishes inter-firm comparability (Bontis et al., 1999). As also noted above, employee remuneration, staff strength and revenue-based measures are frequently used in measuring human capital (Abdel-khalik, 2003; Seetharaman et al., 2004; Wang, 2008). This study uses staff strength, and staff strength/compensation measures extracted from the financial statements of banks in Nigeria.

\subsection{Market Valuation of Human Capital}

The capital market is in need of more information on managerial quality, innovatory skills, experience, workforce integrity and other intangible resources of reporting entities. The disclosure of such information will assist the investing public and other market participants in making sound economic decisions (Dumay and Tull, 2007; Garcia-Meca, 2005). An examination of market value and intellectual capital disclosure of 58 companies showed that these disclosures had a significant effect on market 
capitalization (Abdolmohammadi, 2005). Similarly, Vergauwen et al. (2007) found a highly significant correlation between market capitalization and intellectual capital.

Human capital is the key component of intellectual capital as it is capable of creating value and dealing with turbulent and competitive business environments. It seems reasonable; therefore, to expect that the differential possession of human capital stock will correlate with market valuation. Wang (2008) investigated, among other things, the relationship between human capital and market value of firms in the US electronic industry from 1996 to 2005. The study used number of employees and proxies for human capital, and found a significant relationship between human capital and market value. Given the findings of previous studies, it is reasonable to expect that staff strength will be positively related to market value; therefore, the first hypothesis for this study is as follows:

\section{$\mathrm{H} 1:$ Overall staff strength is positively associated with the market value of firms}

Darby et al. (1999) argued that high-tech firms rely more on the knowledge and capabilities of key personnel than on physical assets. Firms built around very highly productive scientists are most likely to record successfully, commercialized breakthrough technologies, and would therefore have higher market values than similar firms with relatively lower level of human capital endowment. Findings of the study, confirmed the hypothesis that the market value of biotech firms (as well as jumps in market value) are significantly and positively related to the number of star scientists associated with the firm.

Using Towers Perrin's total rewards framework, Hurwitz et al. (2002) examined how the management of human and organizational capital affects the growth of intangibles' performance. Results of one of the regression analyses showed that a long term compensation variable had a significant effect on the performance of intangibles. Since employee compensation is a measure of human capital, the study concluded that human capital is an important driver of intangibles performance, and by extension, a determinant of stock returns. The equity market recognizes and values labour skills and the relative incentive compensation disclosed in the financial statements of listed entities (Abdel-Kalik, 2003); therefore, detailed examination of human capital information disclosed by firms, can assist investors and other market participants in forming opinion about the future performance of listed stocks (Royal and O'Donnell, 2008).

Barney (1999) has suggested that organizational resources can be differentiated based on value and rareness. Valuable resources that are rare can contribute substantially to sustained competitive advantage. Top managerial talent is a rare and valuable resource. Since the equity market recognizes and values relative employee compensation (Abdel-khalik, 2003), and the market value of a firm is associated with the number of valuable specialists tied to it (Darby et al., 1999), it seems reasonable to expect that the number of employees in the top salary ranges of the banking industry will be valued by the market. Therefore, the second and third hypotheses for the study are as follows:

$\mathrm{H} 2$ : The number of highly paid employees in a firm is positively related to the market value of the firm

H3: The number of highly paid employees relative to the overall staff strength of the firm is positively associated with the market value of the firm

The number of highly paid employees relative to the overall staff strength is a proxy constructed from staff numbers and remuneration categories disclosed in the published financial statements of banks in Nigeria. The construction of proxies to measure various dimensions of human capital is a common practice in human capital research. Unfortunately, this practice has led to a large and growing number of human capital indicators. To date, there is no consensus on how best to measure human capital; therefore, the valuation of human capital remains an issue for more research.

\subsection{Human Capital Theory}

The term "capital" was defined by Irving Fisher as the stock of wealth existing at a particular time. Thus, any stock (whether physical or intangible) would qualify as "capital" if it can generate income. Leaning on Fisher's view of capital, Theodore W. Scultz elaborated the view that human capital is a special category of capital with productive capacity and ability to contribute to income as other income generating assets (Nerdum and Ericksen, 2001; Kwon, 2009). Human capital is generally viewed as the knowledge and 
skills embodied in individuals that enable them to contribute to organizational success and socio-economic well-being. Therefore, the accumulation of productive knowledge and skills will enhance productivity and increase organizational value.

There are different kinds of knowledge and skills, some of which are innate. Knowledge and skills that arise from nature and nurture (without any deliberate effort at improvement through formal education and training) may be regarded as the foundation of human capital. Exposure to increasing levels of education and training will also increasingly affect the quality of human capital. Human capital theory recognizes that individuals can invest in themselves through exposure to various knowledge accumulation processes. An entity can also invest in its employees to increase organizational productivity (Nerdum and Ericksen, 2001). Because human capital can affect productivity, which will affect profitability, human capital theory proposes that the market will value the differences in human capital quality.

\section{Methodology of research}

\subsection{Research Design}

Human capital is an intangible asset, and its value is not captured in traditional financial statements. However, human capital indicators can be extracted from annual reports and accounts issued by listed companies. This study used a cross sectional research design which relates human capital indicators to the market value of banks in Nigeria.

\subsection{Sample Selection}

In 2010, there were special regulatory interventions in the Nigerian banking industry. The interventions followed public outcry that some banks were not able to meet their obligations timeously. Investigations by the Central Bank of Nigeria showed that seven banks were in such grave financial position that the banks reported huge amounts of negative capital at the end of 2010 financial year. This situation raised doubts about the going concern status of the banks and impelled the Central Bank of Nigeria to embark on a rescue mission in order save depositors fund (Sanusi, 2011). The seven banks with severe financial difficulties were excluded from the sample for reasons of going concern applicability. Another reason for excluding the seven banks is that the recognition of gains on loans sold to the Asset Management Corporation of Nigeria (AMCON) in 2010 greatly distorted the reported net income of the banks. Since net income is one of the variables used in computing some human capital indicators, the distortion of net income will greatly affect the validity of this study. As an example, the profit and loss account of Union Bank of Nigeria Plc for the year ended 31 December, 2010, showed a gross earning of $\mathrm{N} 113 \mathrm{bn}$, but the profit after tax was N118bn. Thus the profit after tax was greater than the gross earnings of the bank!. This unusual profit positions was because of the recognition of gains arising from loans sold to AMCON by Union Bank in its 2010 financial statements.

The sample for this study, therefore, comprises the remaining fourteen banks, namely Access Bank Plc, Diamond Bank Plc, Ecobank Plc, Fidelity Bank Plc, First Bank of Nigeria Plc, First City Monument Bank Plc, Guaranty Trust Bank PIc, Skye Bank Plc, Stanbic IBTC Bank Nigeria Plc, Sterling Bank PIc, United Bank for Africa Plc, Unity Bank Plc, Wema Bank Plc and Zenith Bank Plc. Data on relevant human capital indicators were extracted from the financial statements of the selected banks for five years, 2010 to 2014. The stock market prices of these firms were obtained from the Daily Summary of the Nigerian Stock Exchange, Port Harcourt, Nigeria.

\subsection{Variables and Model}

The model for this study relates market value to human capital indicators. To examine this relationship the model includes three human capital measures - overall staff strength (OSS), number of highly paid employees (NHPE), and proportion of highly paid employees (PHPE). The first measure is a general human capital proxy, while the second measure (NHPE) is an industry-specific human capital proxy as a common criterion was used in determining the number of highly paid employees across the selected banks. NHPE is a proxy with both staff strength and compensation attributes. The third human capital proxy, proportion of highly paid employees (PHPE) is constructed from the other two variables. The last 
independent variable in the model - earnings per share (EPS) - is a control variable. EPS was included in the model as prior studies have shown that one of the drivers of market price in the equity market is earnings per share (Kailunki et al., 1998). The model is as follows:

$$
M P_{i}=\beta_{0}+\beta_{1} \mathrm{NHPE}_{i}+\beta_{2} \mathrm{OSS}_{i}+\beta_{3} \mathrm{PHPE}_{i}+\beta_{4} \mathrm{EPS}_{i}+\varepsilon_{i}
$$

NHPE is calculated from the salary ranges disclosed in the annual report and accounts of listed banks in Nigeria. Each bank maintains uniform salary range from year to year; but the salary ranges in the banking industry are not uniform. The highest salary range for some banks is "N6m and above", but one bank Wema Bank Plc - reported "N3.1m and above" as its highest salary range. Wema Bank's highest salary range is rather low, considering that some banks' topmost salary range is "N9m and above". The highest salary range reported by First City Monument Bank is "N5.5m and above". The number of employees earning more than $\mathrm{N} 5.5 \mathrm{~m}$ per annum are few, even among the banks reporting higher salary ranges. For the purpose of reporting on a common basis, the number of employees paid N5.5m and above was used in determining the NHPE for all the banks. Other than the highest salary range of Wema Bank Plc which is too low for the industry, "N5.5m and above" is the lowest, topmost salary range that can accommodate all the banks.

The variables in the model are determined as follows:

MP = Market price (MP) is the stock market price at 31 December. The figures were obtained from the Daily Official Summary of the Nigerian Stock Exchange.

OSS = Overall staff strength (OSS) is the total number of employees disclosed in the Annual Reports and Accounts of Banks

NHPE = Number of highly paid employees (NHPE) is the number of employees earning N5.5m and above, annually

PHPE = Proportion of Highly Paid Employees (PHPE) is calculated by dividing number of highly paid employees (NHPE) by the overall staff strength (OSS).

EPS $=$ EPS is earnings per share disclosed in the annual report and accounts.

$\varepsilon_{i} \quad=\quad$ Error term

\section{Results and Discussions}

\subsection{Descriptive statistics and bivariate correlations}

Table 1 presents the descriptive analysis of market value and the human capital variables used in the study. The number of highly paid employees is about thirty per cent of the overall staff strength in the banking industry. The minimum stock price per share is N0.50 which is the same amount with the nominal value of shares in the industry. Averagely, the market price of shares in the industry is N8.28. This compares favorably with some industries, for instance, the insurance industry in Nigeria, where the share price of many firms in the industry is almost static at N0.5 per share. The mean of earnings per share (EPS) is 106k, indicating that banks in Nigeria are generally profitable.

Table 1. Descriptive statistics

\begin{tabular}{|l|c|c|c|c|c|c|c|}
\hline & $\mathbf{N}$ & Minimum & Maximum & Mean & Std. Deviation & Sum & Range \\
\hline MV & 57 & 0.5 & 28 & 8.27 & 7.61361 & 471.91 & 27.5 \\
\hline NHPE & 57 & 2 & 5251 & 1569.12 & 1331.278 & 89440 & 5249 \\
\hline OSS & 57 & 1158 & 12969 & 4892.05 & 3330.348 & 278847 & 11811 \\
\hline PHPE & 57 & 0 & 0.55 & 0.30 & 0.15041 & 17.18 & 0.54 \\
\hline EPS & 57 & -157 & 347 & 106.21 & 115.3115 & 6054 & 504 \\
\hline
\end{tabular}

Source: The study. Variables are defined as follows: MV is market value, NHPE is number of highly paid employees, OSS is overall staff strength, PHPE is the ratio of NHPE to OSS; EPS is earnings per share. Note: Some banks did not disclose salary ranges with effect from 2012 when they started reporting under IFRS

Table 2. Pearson Correlations

\begin{tabular}{lccccc} 
& MV & NHPE & OSS & PHPE & EPS \\
\hline MV & 1 & $.346^{* * *}$ & 0.133 & $.504^{* * *}$ & $.724^{* * *}$ \\
NHPE & $.346^{* * *}$ & 1 & $.734^{* * *}$ & $.703^{* * *}$ & $.540^{* * *}$ \\
OSS & 0.133 & $.734^{* * *}$ & 1 & 0.192 & $.307^{* *}$
\end{tabular}




\begin{tabular}{lccccc} 
& MV & NHPE & OSS & PHPE & EPS \\
\hline PHPE & $.504 * * *$ & $.703^{* * *}$ & 0.192 & 1 & $.545^{* * *}$ \\
EPS & $.724 * * *$ & $.540 * * *$ & $.307^{* *}$ & $.545^{* * *}$ & 1 \\
\hline$* * *, * *$ & Correlation significant at the 0.01 & and 0.05 & level, respectively
\end{tabular}

Table 2 presents the bivariate correlations of the variables used in the study. Overall staff strength (OSS) is not significantly correlated with market price (MP), but the proportion of highly paid employees (PHPE) is positively and significantly correlated with MP at the 1 per cent level, suggesting that the number of staff employed by a bank is not as important as the proportion of highly paid employees (PHPE) in the equity valuation of the bank. Overall staff strength (OSS) is also not significantly correlated with proportion of highly paid employees (PHPE), suggesting that the proportion of highly paid employees (PHPE) does not necessarily increase with overall staff strength (OSS) of a bank.

Table 3. Multiple regression results

\begin{tabular}{|c|c|c|c|c|c|c|}
\hline Variables & Coefficient & t-stat & Sig. & VIF & \multicolumn{2}{|c|}{ Model Summary } \\
\hline NHPE & -0.389 & -1.554 & 0.126 & 7.586 & $\mathrm{R}^{2}$ & 0.571 \\
\hline OSS & 0.135 & 0.748 & 0.458 & 3.945 & Adjusted $\mathrm{R}^{2}$ & 0.538 \\
\hline PHPE & 0.377 & 2.125 & 0.038 & 3.804 & Durbin Watson & 1.771 \\
\hline EPS & 0.688 & 6.116 & 0.000 & 1.531 & F-Statistic & 17.29 \\
\hline & & & & & Sig. & 0.000 \\
\hline
\end{tabular}

Dependent variable: market price. Source: Authors' computation

\subsection{Empirical Results}

Table 3 presents the results of regression of market price (MV) on human capital variables (NHPE, OSS, PHPE) and the control variable (EPS). The model summary shows that the model has a good fit with an $\mathrm{R}^{2}$ of 57 per cent, suggesting that the independent variables explain more than 55 per cent of variations in the market price of shares in the banking industry. The model summary shows a p-value less than alpha at 0.01 , and a Durbin-Watson statistic of 1.771 which suggests that the problem of autocorrelation is not a serious issue in this study. Also, the variance inflation factor (VIF), which quantifies the extent to which the variance of estimated coefficients are inflated, is less than 10 for each independent variable, suggesting that multicollinearity is not such a serious problem that requires correction in order to present a robust result in this study.

Results in Table iii further show that the coefficient on overall staff strength (OSS) is not significant, suggesting that investors in the Nigerian banking industry do not perceive the number of staff engaged by a bank as a very important measure for equity valuation. The result is not consistent with studies that found that staff strength is an important driver of firm value (Wang, 2008). This result may be due to the understanding that many of the staff in the banking hall of many banks in Nigeria are actually on temporary appointment. The issue of numbers may therefore not impress investors. This general impression on staff numbers may also explain the non-significant relationship between number of highly paid employees and market price of shares.

The results further show that proportion of highly paid employees (PHPE) is positively and significantly associated with market price (MP), suggesting that the strength of valuable human resource in the staff structure of banks is recognized and valued by the market. This result is consistent with the literature which suggests that valuable resources are useful in achieving and sustaining competitive advantage (Barney, 1999). Thus a firm with a high proportion of highly paid employees will receive more favourable market valuation than the firm with a low proportion of highly paid employees. Table iii also shows that earnings per share (EPS) are positively and significantly associated with market price, indicating that investors have confidence in the earnings numbers posted by banks in Nigeria. This is possible because of the interventions of the Central Bank of Nigeria in the banking sector in 2010 when some banks with negative capital suffered regulatory penalties (Sanusi, 2011). The significant positive association of earnings per share and market price is supported by several studies in the field of value relevance research (Bartov et al., 2005; Kailunki et al., 1998). 


\section{Conclusions}

A number of studies have attempted to establish a link between organizations' stock of human capital and their market valuations. These studies encountered problems with the valuation of human capital because of the complex nature of its stock, and the absence of a generally accepted, all-inclusive system that measures all dimensions of human capital. Accordingly, most studies constructed different valuation systems and these efforts have led to a multitude of human capital metrics. To date, there is lack of empirical consensus on how best to measure the knowledge and skills embodied in individuals; therefore, measuring human is still an issue calling for more research.

This study used secondary data from the Nigerian banking industry for a period of five years (2010 to 2014). Results of the study show that certain human capital indicators (overall staff strength and number of highly paid employees) did not significantly affect the market valuation of banks in Nigeria. However, the proportion of highly paid employees is significantly and positively related to market value, suggesting that the higher the strength of highly paid employees relative to overall staff strength the more a firm can sustain competitiveness and this affects how the market values the firm. Thus, banks with a greater proportion of highly paid employees will be able to create more value and receive more favourable market valuation than those with lesser proportion of this manpower quality. Further studies may consider whether the market value of banks with greater proportion of highly paid employees is driven by the ability of these banks to better exploit the collective knowledge and skills of the employees.

\section{References}

1. Abdel-khalik, R.A. (2003). Self-sorting, incentive compensation and human capital assets. European Accounting Review, 12(4), 661-697.

2. Abdolmohammadi, M.J. (2005). Intellectual capital disclosure and market capitalization. Journal of Intellectual Capital, 6(3), 397-416.

3. Abeysekera, I. (2008). Intellectual capital practices of firms and commodification of labour. Accounting, Auditing and Accountability Journal, 21(1), 36-48.

4. Arenas, T., \& Lavandos. L. (2008). Intellectual capital: object or process?. Journal of intellectual capital, 9(2), 77-85.

5. Armstrong, M. (2006). A Handbook of Human Resource Management Practice. London: Kogan.

6. Barney, J. (1991). Firm resources and sustained competitive advantage. Journal of Management, 17, 99-120.

7. Bartov, E., Goldberg, S.R., \& Kim, M. (2005). Comparative value relevance among German, U.S., and International Accounting Standards: A German Stock Market Perspective. Journal of Accounting, Auditing \& Finance, 20(2), 95-119

8. Bilich, F., \& Silva, R. (2006). Valuation and optimization of intellectual capital. Brazilian Journal of Business Economics, 6(2), pp. 25-37.

9. Bontis, N. (2001). Assessing knowledge assets: a review of the models used to measure intellectual capital., International Journal of Management Reviews, 3(1), 41-60.

10. Bontis, N., Dragonetti, N.C., Jacobsen, K., \& Roos, G. (1999). The knowledge tool box: a review of tools available to measure and manage intangible resources. European Management Journal, 17(4), 391402.

11. Bose, S., \& Thomas, K. (2007). Valuation of intellectual capital in knowledge based firms: the need for new methods in a changing economic paradigm. Management Decision, 45(9), 1484-1496.

12. Bryant-Kutcher, L., Jones, D.A. and Widener, S.K. (2009). Market valuation of intangible resources: The use of strategic human capital. Advances in Management Accounting, 17, 1-42.

13. Carson, E., Ranzijn, A., Winefield, A., \& Marsden, H. (2004). Intellectual capital: mapping employee and work group attributes. Journal of Intellectual Capital, 6(3), 443 -463.

14. Cheng, M., Lin, J., Hsiao, T., \& Lin, T.W. (2008). Censoring model for evaluating intellectual capital value drivers. Journal of Intellectual Capital, 9(4), 639-654.

15. Choong, K.K. (2008). Intellectual capital: definitions, categorizations and reporting models. Journal of Intellectual Capital, 9(4), 609-638. 
16.Darby, M.R., Liu, Q., \& Zucker, L.G. (1999). Stakes and stars: The effect of intellectual human capital on the level and variability of high-tech firms' market values, Working paper, National Bureau for Economic Research, Cambidge, MA. Retrieved from http://www.ideas.repec.org/p/nbr/nberwo/7201.html/

17.Dumay, J.C., \& Tull, J.A. (2007). Intellectual capital disclosure and price-sensitive Australian Stock Exchange announcements. Journal of Intellectual Capital, 8(2), 236-255.

18.Dressler, G. (2008). Human resource management, New Jersey: Pearson Education, Inc.

19.Fitz-enz, J. (2009). The ROI of human capital: Measuring the economic value of employee performance. New York: AMACOM.

20.Garcia-Meca, E. (2005). Bridging the gap between disclosure and use of intellectual capital. Journal of Intellectual Capital, 6(3), 427-440.

21.Gadzar, K. (2007). Reporting Nonfinancials, John Wiley \& Sons, West Sussex.

22.Hurwitz, J., Lines, S., Montgomery, B., \& Schmidt, J. (2002). The linkage between management practices, intangible performance and stock returns, Journal of Intellectual Capital, 3(1), 51-61.

23.Kannan, G., \& Aulbur, W.G. (2004). Intellectual capital: measurement effectiveness. Journal of Intellectual Capital, 5(3), 389-413.

24.Kailunki, J., Martikainen, M., \& Martikainen, T. (1998). Accounting Income, Income components and market-to-book equity ratios: Finnish evidence. The International Journal of Accounting, 33(3), 359-379

25.Laroche, M., Mérette, M., \& Ruggeri, G.C. (1999). On the concepts and dimensions of human capital in a knowledge-based economy. Canadian Public Policy - Analyse de Poliques, 25(1), 87-100.

26.Le, T., Gibson, J., \& Oxley, L. (2003). Cost and income based measures of human capital. Journal of Economics Surveys, 17 (3), 271-301.

27.Lepak, D.P., \& Snell, S.A. ((2002). Examining the human resource architecture: The relationships among human capital, employment and resource configurations. Journal of Management, 28(4), 517-543.

28.Nerdum, L., \& Erickson, T. (2001). Intellectual capital: A human capital perspective. Journal of Intellectual Capital, 2 (2), 127-135.

29.Organisation for Economic Cooperation and Development (2001). The well-being of nations: the role of human and social capital. Retrieved from www.oecd.org/site/worldforum/33703702.pdf/.

30.Rostogi, P.N. (2000). Knowledge management and intellectual capital: the new virtuous reality of competitiveness. Human Systems Management, 19, 39-48.

31.Royal, C., \& O'Donnell, L. (2008). Differentiation in financial markets: the human capital approach. Journal of intellectual Capital, 9 (4), 668-683.

32.Sanusi, S.L. (2011). Public Statement on the recapitalization of eight Nigerian banks. Retrieved from www.cenbank.org/Out/2011/pressrelease/gvd.

33.Seetharaman, A., Helmi, H., \& Saravanan, A.S. (2002). Intellectual capital accounting in the knowledge economy. Journal of Intellectual Capital, 3(2), 128-148.

34.Seetharaman, A., Low, K., \& Saravanan, A. (2004). Comparative justification on intellectual capital. Journal of Intellectual Capital, 5 (4), 522-539.

35.Sulanjaku, M. (2014). The contribution of Skandia Navigator in intangibles measurements - an Albanian case approach. International Journal of Economics, Commerce and Management, 11 (11), 1-10.

36.Swart, J. (2006). Intellectual capital: Disentangling an enigmatic concept, Journal of Intellectual Capital, 7(2), 136-159.

37.Tayles, M., Bramley, A., Adshead, N., \& Farr, J. (2002). Dealing with the management of intellectual capital: the potential role of strategic management accounting. Accounting, Auditing and Accountability Journal, 15(2), 251-267.

38.Vergauwen, P., Bollen, L., \& Oirbans, E. (2007). Intellectual capital disclosure and intangible value drivers: An empirical study. Management Decision, 45 (7), 1163-1180.

39.Wang, J. (2008). Investigating market value and intellectual capital for S\&P 500. Journal of Intellectual Capital, 9(4), 546-563.

40.Zhang, H., \& Jin, R. (2006). Value-added of human capital through complementary capital. The Journal of American Academy of Business, 9(1), 191-196. 